Boise State University ScholarWorks

Marketing and Finance Faculty Publications and

Presentations

Department of Marketing and Finance

10-1-2009

\title{
Guiding Tourists to Their Ancestral Homes
}

Nina M. Ray

Boise State University

Gary McCain

Boise State University 


\title{
Guiding Tourists to Their Ancestral Homes
}

\author{
Nina M. Ray and Gary McCain \\ Boise State University
}

\begin{abstract}
Purpose: This paper introduces measures of the motivation of tourists who travel to their ancestral homes. A set of learning exercises is presented for students and managers to apply understanding of these motives to tourism strategies.

Design/Methodology/Approach: This paper provides a brief review of the literature of heritage tourism and the special segment that travel with genealogical objectives. Survey data on motives to seek out ancestors is provided with learning exercises to link motives to tourism planning.

Findings: Data on the importance of multiple motives is presented with analytical measures of their overall importance levels and of differences between U.S. and U.K. samples.

Research Limitations/Implications: The motivational variables and data collection are primarily exploratory, focusing on samples that are interested in genealogy and heritage tourism. Further research could certainly be expanded to cover broader populations of tourists and genealogists.

Practical Implications: By combining primary research with trade association research included in this paper students and tourism managers have the opportunity to apply research findings to tourism and hospitality decision-making to attract and satisfy tourists who have genealogical goals in their travel agendas.

Originality/Value: Data based on the important and growing domain of motivational research in ancestral/genealogical related tourism has not been presented for analysis and application until now. Strength of motives and differences between nationalities of tourists presents a unique analytical opportunity in learning exercises.
\end{abstract}

Key Words: tourism, legacy tourism, heritage tourism, genealogy, Scotland

“What's Your Story?” is an advertising campaign by CITICARD that aired 2007/2008 in the United States (Father and Son, 2007).

So I asked my dad where he wanted to go for his $60^{\text {th }}$ birthday.

"Norway," he said, "the land of our ancestors."

We drank a pint at Ibsen’s favorite pub. We sampled the local fare.

We saw fjords; we got new sweaters.

We bonded. "It was the trip of a lifetime," Dad said.

And so, we went to the Hall of Records to trace our family tree and discovered that we were actually

Swedish!

“Two tickets to Stockholm, please. Let’s go."

From visiting old words to making new discoveries, whatever your story is, CITICARD can help you write it.

CITI CARD; let's get it done.

Even though this report does not include data from Norwegian-Americans, note the reaction from interviews at Sons of Norway Lodge gatherings, in exposing respondents to the CITICARD ad. Many comment on the lack of authenticity of scenes in the ad (such as yodeling, the "Hall of Records," buying ferry tickets to Stockholm.). Authenticity plays a role in perceptions of ancestral tourism sites. However, many were content that Norwegian scenes were shown and that they had recognized (and often, personally visited) those scenes. A few representatives of Swedish organizations were a bit irritated because they thought the characters in the ad looked disappointed to find out that they were Swedish, instead of Norwegian. Many with no Norwegian or Swedish background still remember the commercial and specifically remember the fact that the father and son thought they were Norwegian, but turned out to be Swedish, emphasizing the complexity of tracing one's roots. While the purpose of this ad 
This is an author-produced, peer-reviewed version of this article. The final, definitive version of this document can be found online at International Journal of Culture, Tourism and Hospitality Research, published by Emerald. Copyright restrictions may apply. DOI: $10.1108 / 17506180910994514$

clearly was not to encourage tourism to Norway or Sweden, the message highlights the emerging reality that many North Americans engage in "ancestral" (or "legacy," "roots," or "family heritage") travel. They cheerfully and enthusiastically spend money to travel to distant lands, sometimes with minimal information, to seek out and verify what they know or want to know about their heritage.

Garrod and Fyall (2000) report that heritage tourism is a major growth area and find that typical heritage tourists are older, with an interest in nostalgia. They are often wealthy. Interest and research on heritage/culture tourism has generated numerous equally interesting definitions of such tourism (Balcar and Pearce, 1996). Garrod and Fyall (p. 683) quoted Yale (1991, p. 21), "tourism centred on what we have inherited, which can mean anything from historic buildings, to art works, to beautiful scenery". For the purpose of this research the definition for heritage/culture tourism is "visits by persons from outside the host community motivated wholly or in part by interest in the historical, artistic, scientific or lifestyle/heritage offerings of a community, region, group or institution”, (Silberberg 1995, p. 361).

Palmer (2005, p. 7) explores "Englishness" as "identity through tourism” and finds that many visitors to important national sites are interested in "our way of life" and "our ancestral line" (p. 22). Sometimes the two are blurred as Churchill seems to be perceived as "our honorary relative." This felt history "is illustrated by the intermingling of phrases and images of home, family, kinship, ancestors and common blood, with expressions of emotion and feeling. It is this intermingling that enables the internal, intimate function of national identity to promote a sense of belonging, a sense of place” (p. 22). A sense of Englishness (or Scottishness, or Irishness), whether by citizenry or ancestry, can connect one's personal identity to a sense of place.

Nicholls, Vogt, and Jun (2004) identify specific types of heritage tourism including "legacy” tourism--travel related to genealogical endeavors (McCain and Ray, 2003).

What is remarkable about heritage, however, is its power of working in the present in a way that has recourse to the past, in a way that interprets the past into something that we learn to understand as "history.” (Câmpeanu, 2003, p. 357)

Many tourists learn "to understand as history" through their own family history.

Nicholls et al. (2004) cites the Travel Industry Association of America (2003) estimate that around 81 percent of U.S. adults taking a trip in 2002 are classifiable as heritage or cultural tourists. This tourist classification represents a 13 percent increase since 1996. The Wall Street Journal also reports, that a "widespread interest in genealogy is sweeping America” (Dickerson, 2006, p. W15). Therefore, determining ancestral tourists' motivations takes on even more importance because this specific sub-segment of heritage tourists is growing.

Look to Salt Lake City's Family History Library to discover the importance of genealogical tourists to a community. Many of the Library's daily 1,900 visitors (only a minority are Mormons) come from other countries (Eastman's Online Genealogy Newsletter, 2006). Many people also view websites (e.g., www.visitsaltlake.com/what_to_do) that prominently display genealogy information.

Genealogy is a "significant part of Northern Ireland's tourism industry" (Evans, 1998, p14), and contributes to part of approximately 200 million pounds revenue per annum from foreign visitors (Collins and Beggs, 2000). In the North of Ireland, the Department of Culture, Arts and Leisure sponsors a "comprehensive examination of genealogy-related services" recognizing the "role of family history in promoting tourism” (Mackenzie, Slater, and Roberts, 2004). Yet, as Garrod and Fyall (2000) report, many heritage managers do not really consider themselves to "be in the tourism business" (p. 684). Regarding genealogy tourism, many heritage managers notice the negative economic impact when ancestral-seeking tourist numbers decline. According to Heinlen (2007), increases in on-line genealogy searches have "been an economic boost for online companies that specialize in genealogy", however, "it has had the unintended consequence on Ireland of decreasing the incoming revenue of the genealogy tourism industry." Therefore, tourism managers need to thoroughly understand the motives of tourists who travel to their ancestral homes. While ancestral research may be a key motivator for these tourists, Garrod and Fyall (2000) found that heritage tourists also want a general leisure experience. Tourism managers need to be careful to incorporate ancestral tourism activities into broader entertaining leisure experiences. 
This is an author-produced, peer-reviewed version of this article. The final, definitive version of this document can be found online at

International Journal of Culture, Tourism and Hospitality Research, published by Emerald. Copyright restrictions may apply. DOI: 10.1108/17506180910994514

According to the sponsors of the 2008 Who Do You Think You Are? National History Show in London in May, "As the largest event of its kind, the entire event will attract up to 20,000 visitors from across the UK. This innovative, national event is set to become the premium event for anyone with an interest in the history market: an unbeatable opportunity to meet new customers and develop your business." Exhibitors will "have the chance to meet an articulate, and highly educated ... consumer - each with money to spend on a subject that is important to them" (Exhibiting, 2008). Therefore, not only is there a large population of history-seeking visitors, but these consumers have demographics favorable to marketers.

\section{Ancestral Tourism Data}

While tracing her own family tree, the lead author began to wonder whether or not other tourists' interests include traveling (and spending money) to seek information about their ancestry. She investigated genealogy tourism records in countries of personal interest. While learning more about her family's ancestry, the number of countries expanded due to personal and increasingly professional interest. Directors of heritage institutions in Northern Ireland (the location of her own ancestral interest) encouraged further digging. To her surprise, a significant amount of some nations' tourism revenues derives from ancestral tourism.

The preceding served as a catalyst to initiate a long-term research project investigating North Americans' motivations to rediscover their ancestral roots. At the beginning of the research, surveys were administered at heritage group meetings. To identify other heritage groups, snowball sampling was employed. Eventually, the data collection process extended to European events. For example, one family history society in Scotland recommended a larger group in a nearby city.

Survey respondents for the legacy tourism project were recruited from meetings and activities of cultural and historical societies. Each potential respondent was asked to complete a one-page (two-sided) survey either at the gathering or at one's convenience to be mailed back later. Gathering data in situ allows the researcher to engage in conversations and often to conduct fairly long interviews with respondents. As Martin (2007) describes, the long interview is valuable in examining influences and consequences of leisure decisions. Sometimes, consequences are potentially risky and less than desirable when "skeletons in the closet" are found. By conversing in person, the researcher can learn about the range of outcomes, both good and bad.

Questions about motivations to rediscover family history derived from Basu (2004) and feedback from early interviews. Questions concerning typical travel behavior originate from Eagles' (1992) investigations with Canadian heritage (ecotourism) travelers. Response rates are often 50 percent of people attending heritage-related gatherings. The total sample in this study came from twenty US events and nine Scottish events and other events in Northern Ireland, Nova Scotia and Wales ( $\mathrm{n}=684)$.

The set of motivations often were reinforced by comments made to researchers. For example, one tour guide in Scotland is amazed that the first words out of North Americans' mouths arriving in Scotland are often, "I feel like I've come home." Nine of 17 motivations to learn about family heritage differed significantly between UK citizens (primarily of Scottish descent) and US citizens (around 30 percent of Scottish descent). Results are shown in Table 1.

\section{Table 1 about here.}

Table 2 shows the average age of the two groups and response to general travel behavior.

\section{Table 2 about here.}

In a separate regression run (not shown here), the independent variables of age, percent of foreign travel, and percent of leisure travel are regressed on the dependent variable of the importance of visiting "place where family is from." The model is not significant, showing that demographics do not affect the importance of visiting ancestral sites. In a correlation analysis, only age is related significantly to the travel reason of creating long-standing relationships and friendships ( $<<.01)$. This relationship is inverse - older respondents are less concerned than younger respondents. On the other hand, age is positively and significantly related to the total percent of leisure travel (versus business). Perhaps less obvious is age's positive relationship with foreign travel (versus domestic travel) $(\mathrm{p}<.05)$. 
This is an author-produced, peer-reviewed version of this article. The final, definitive version of this document can be found online at

International Journal of Culture, Tourism and Hospitality Research, published by Emerald. Copyright restrictions may apply. DOI: 10.1108/17506180910994514

\section{"Highland" Heritage}

Scotland's heritage plays an important role in ancestral tourism research. In Highland Heritage, Celeste Ray (2001) describes how Scottish descendents living in the U.S. identify and follow the "traditions" of Scottish immigrant ancestors. Many Scottish descendents display their association in activities (e.g., tartan wearing or highland games) invented a century after their ancestors immigrated to North America (including many from the lowlands, although this geographic area tends to be ignored in North American heritage memory). Most heritage participants and attendees agree with the Scottish-Americans. They are "looking for authentic inauthenticity" (Brown, Hirschman, and Maclaran, 2000, p. 171). These people are sometimes disappointed not having their expectations met when visiting the "old country." Some researchers in Scotland analyze Scottish folksongs to investigate the "multiple flows" of authenticity for tourist spectacles (e.g., Knox, 2008). Basu's (2004) research from Scotland reports that these visitors to the ancestral homeland are sometimes ridiculed and considered to be "emotional cripples" by the locals. One question is whether or not differences exist between the motivations of descendents of those in the "diaspora" who engage in ancestral tourism versus those who live in the "old country." This reflection is timely because Scotland is planning for the 2009 Homecoming Scotland project to celebrate the $250^{\text {th }}$ anniversary of Robert Burns' birth (Homecoming Scotland, 2008). According to Basu (2007), at least 28 million people in the world have Scottish ancestry.

Recently, Donald Trump, a famous American of Scottish descent, made the news when his plans to build a luxury golf course were turned down (then the rejection overturned) by the Aberdeenshire Council's Infrastructure Committee. Trump often referred to his Scottish heritage during his battle with the Council (MacDonald, 2007; Trump's Golf-Resort Plan in Play 2007). Trump also created controversy when his invented coat of arms for the resort had not received heraldry approval by the Lord Lion of Scotland. However, "In an unprecedented move, six of the country's largest business organizations have joined forces to highlight the risk to long-term investment if delays over Mr. Trump’s development at Balmedie continue” (Maclarty, 2008, p. 1). Sustainable economic results must be assured, along with heritage protection.

Basu (2007) discusses how Ancestral Scotland poses questions such as "Where do you come from?" and "When will you come home?” These tourism messages came after VisitScotland undertook research that found genealogy tourism, golf, and culture are "prime importance in attracting visitors" (Scottish Roots, 2004). Their research identified four primary motivators for ancestral travel: to access more information about their ancestors, to see the places where their ancestors lived, to connect with other people, and to connect with self (Ancestral Tourism, 2006). VisitScotland used the results to develop a training program to assist tourism professionals implement promotional activities consistent with the study's findings. Many international tour operators conduct ancestral tours. Figure 1 details three itineraries of recent trips.

\section{Figure 1 about here.}

\section{Learning exercise}

A student intern receives the assignment to assist a Scottish tourism association to develop a training seminar. The seminar's purpose is to take advantage of the emerging heritage and legacy tourism market segment. The first step involves visiting online sites promoting genealogical research and tourism in Scotland (e.g., www.ancestralscotland.com or www.homecomingscotland.com) to see how genealogy and tourism currently are promoted. The intern notes that most of the online sites feature locations, events, and genealogical tourists or tourism professionals with their legacy tourism concerns. As that intern, complete the following tasks and answer the questions:

1. Consider the motivations of tourists interested in travel relating to genealogical interests. What travel activities correspond to the motivations that are most important to them?

2. How might tourists from the United Kingdom different from tourists from the United States? How would you design a group tour for each group? See the VisitScotland research (Ancestral Tourism, 2006;

“Tourist Board Training”, 2008)

3. Build a list of training session topics you would want to include for tourism managers (agencies, destination organizations, professional genealogists) that would help them respond to the motivations of legacy tourists. 
This is an author-produced, peer-reviewed version of this article. The final, definitive version of this document can be found online at International Journal of Culture, Tourism and Hospitality Research, published by Emerald. Copyright restrictions may apply. DOI: $10.1108 / 17506180910994514$

4. Identify some specific activities to include when building a travel web site guide for tourists to Scotland. Be sure to include information for tourists traveling on their own based on non-legacy motivations. Which would you expect to be of greater interest to Americans than Scots?

5. What advice would you give to managers of destination sites and events (e.g., Inverness, Eilean Donan Castle, or Edinburgh Festival) to better serve legacy tourists?

6. Describe the types of organizations that would be interested in learning about legacy tourism motivations and attending your training seminar in addition to tourism managers.

7. Evaluate the research methodology used in this research. Discuss the methodology's appropriateness for this type of marketing decisions.

8. Compare what agencies in Scotland are doing to address legacy tourism with efforts employed by another country.

9. Based on the data presented earlier in this paper, evaluate the two itineraries in regard to how well they might meet the needs of legacy tourists. Are there universal legacy itineraries than can be suggested, regardless of tourist's country of origin or the destination?

\section{Trainer Notes}

1. Data in Table 1 show that the range of motivators checked by respondents ranges from a low of five percent to highs over 40 percent. Topping the list are Personal Identity and Connection with Place. How high or how many motivators the instructor wants to address depends on the time and weight given to each exercise. Specific activities also should vary with the students' background knowledge. The personal nature of these top motives should lead most students to recognize that travel expectations are connected to a specific site, name, or document that individual travelers recognize as relevant. Opportunities to search out individual villages and homes, parish or civil records to find ancestors names, and other uniquely personal symbols of their lineage would be highlights of these tourists' visits. In the case of Scotland, it is notable that the Homecoming theme is near the list's bottom, with UK being significantly lower than US.

2. Analyzing differences between the UK and the US requires an understanding of basic statistical analysis (e.g., chi-square). In order of importance, UK respondents rated Connection with Place, Intellectual Challenge, Quest, and Closing the Gap to be more important than did US respondents. On the other hand, US respondents rated in order of importance Obligation to Ancestors, Completing the Circle, Sacred, Community, and Homecoming to be more important than UK respondents. Interpreting why these differences exist would be an interesting discussion. Referring back to Homecoming, and probably relating to other motives, the significantly higher US score relative to the UK suggests almost all Americans have an ancestral home. The British never left their home country, so a homecoming is less meaningful. Obligation to Ancestors is more American, particularly for Mormon (Latter-Day-Saints) respondents who consider their ancestor's well being to depend on religious actions by living descendents. Discussion should address the numerous activities present in the VisitScotland ${ }^{\mathrm{TM}}$ research (Ancestral Tourism, 2008; "Tourist Board Training", 2008) to determine which motives offer most satisfaction to each segment. Enhancing the preferred options should evolve from analyzing relationships between travelers' motives and activities.

3. Several different perspectives should guide responses. First, make sure that the top percentage priorities (e.g., personal identity) are covered to train managers about the necessity to provide flexible tour schedules. Many tourists will want to separate themselves from a group to visit individual home sites. Second, plans also may include coaching and assistance at destination record keeping areas for those whose ancestral motivations exceed their genealogical researching abilities. Guides and itineraries should direct tourists to central records locations which tend to be in the major cities. Such activities can coincide with visits to nearby tourist attractions. Topics drawn from the motivations list and the VisitScotland ${ }^{\mathrm{TM}}$ websites provide background for discussion sessions on why the UK and US visitors have different responses, interests and motivations.

4. For personal identity, connection with place, as well as other historical artifacts (e.g., specific events), a web site connection to online data records would be valued highly by both UK and US tourists. The ability to find public data locating or verifying a place would strengthen the motive to visit the site that "great grandfather was born, married, lived, died.” For Intellectual Challenge, the option of locating a genealogy help site addressing local complex research issues would be desirable. The objective is to use the research to identify what drives tourists to become interested and involved in the destination rather than focus on a set of offerings that may already be provided by another service provider. The significant differences define which activities would be most visited by UK and US web visitors. 
This is an author-produced, peer-reviewed version of this article. The final, definitive version of this document can be found online at

International Journal of Culture, Tourism and Hospitality Research, published by Emerald. Copyright restrictions may apply. DOI: 10.1108/17506180910994514

5. To best serve ancestral tourists, employees at destination sites should recognize that one tourist segment (legacy tourists) is interested in more information than the location's history and the "star" historical figures. These tourists want to know who else was there. Was my great-great grandfather a soldier, blacksmith, or prisoner here? Where do I go to find out? What was his life like?

6. Employees of nearby hotels and restaurants could tie into the clan heritage theme. Libraries and archives in both large cities and rural areas would benefit from sending their employees to training. Rural areas might need the more training since large national archives and libraries typically have marketing managers on staff. Historical societies are another important source. Some historical societies should consider emphasizing legacy tourism to members and plan specific genealogy tours.

Students also should think about opportunities indirectly related to legacy tourism that leverage family history motives. Universities, especially those that recruit abroad, sometimes recruit students with Scottish roots. Some universities also have genealogy programs (e.g., University of Strathclyde in Glasgow). These specialized programs tend to attract more non-traditional students. For example, retirees or people close to retirement could form a target market.

As the Ancestral Tourism (2006) leaflet details, even organizers of golf packages can tie into ancestral tourism. Those controlling fishing rights in Scotland also could emphasize their geographic connection to ancestral lands. Although businesses mainly involved in golf and fishing tourism do not perceive themselves to be in the ancestral tourism business, they could benefit from the specialized training.

7. Research methodologies are easy to criticize. Students should recognize immediately that a nonprobability sample is used. While the sample does seem to be one of convenience, students also should recognize that a "snowball" or referral sample describes the data collection. Snowballing helps to obtain contacts at family history and historical groups. An electronic survey should be considered at some point. Collecting data on-line is both efficient and consistent with the method used by many consumers to obtain their family history data. After collecting nearly 700 cases of in-person data, the researcher should have a fairly good understanding of the reasons and in-depth motivations behind ancestral travel. Electronic surveys would allow for more objective measures. Students could suggest some objective measures for future data gathering.

8. Answers will vary. Some countries emphasize ancestral tourism more than others and they do a better job of promoting the message. Students should consider some general historical immigration history in the response preparation. For example, the Baltics and Eastern Europe experienced emigration due to communist control and might see descendents with different motivations.

Students should make use of their internet skills to gather ancestral tourism marketing information and to evaluate the role that electronic databases play in a country's overall tourism marketing campaigns. Have technological advances helped or hindered the country's ancestral tourism efforts?

9. The exercise emphasizes the importance of "connection with place." Sometimes the place connection is a specific ancestral location. The Welsh-American tour includes visits to National Libraries; the clan tour of Scotland did not. Perhaps some introduction to records research while in Edinburgh could have been included for those interested. "Intellectual challenge" is selected by large numbers of legacy tourists. Scottish tour operators must deal with the Clan phenomenon and might research further the difference between legacy clan tours (who may be more interested in living members of the clan or extended family than in deceased relatives) and those trips taken by those with an expressed interest in genealogy.

Figure 1 shows most legacy tours tend to be made up of women, most of them senior citizens. However, sometimes middle-aged people are legacy tourists too. They tend to take several legacy trips (one particular trip may not be the only legacy trip they will take). Those travelers of a particular religious faith will want relevant religious sites included.

\section{Conclusions}

While the knowledge and theoretical foundation of understanding heritage tourists' motivations are in the early development stages, some motives are clearly strong driving forces. This early research stage already identifies segments based on genealogical tourism motivations between nations as well as some universal values.

Understanding these motives increases effectiveness of service offerings employed by travel agency and tourism destination managers. 
The learning exercise questions present students and practitioners the opportunity to convert conceptual motivation research to product attributes. Specific tourist offerings can be developed to attract and satisfy ancestral tourists. Although this research is exploratory, the data provides strong differential signals for decision-making. Since market segmentation decisions depend on the methodology applied, future research should cover a broader sampling of the population. New methodological approaches will strengthen the research’s reliability and validity. 


\section{References}

Ancestral Tourism (2006), “Partnership Working, Ancestral Tourism Imitative, Tourism

Indicatives”, Visit Scotland, available at:

http://staging.scotexchange.net/ancestral_leaflet_2006_-_low_res-2.pdf_accessed 10 June 2008).

Balcar, M. J. O. and Pearce, D. G. (1996), “Heritage Tourism on the West Coast of New Zealand”, Tourism Management, Vol. 1, No. 3, pp. 203-212.

Basu, P. (2004), “My Own Island Home the Orkney Homecoming”, Journal of Material Culture, Vol. 9, No. 1, pp. 27-42.

Basu, P. (2007), Highland Homecomings: Genealogy and Heritage Tourism in the Scottish Diaspora, Routledge, New York, NY. .

Brown, S., Hirschman, E.C., and Maclaran, P. (2000), “Presenting the past: on marketing’s reproduction orientation,” in Brown, S. and Patterson, A., (Eds.), Imagining Marketing: Art, Aesthetics and the Avant-Garde, Routledge Interpretive Marketing Research, New York, pp. 145-191.

Câmpeanu, C. N. (2003), “Tourism, Modernity, and Heritage Production at the Alamo”, Advances in Consumer Research, Vol. 30, pp. 357-360.

Collins, N. and Beggs, R. (2000), "Government and Tourism in Northern Ireland", in Buttimer, N., Rynne, C. and Guerin, H. (Eds.), The Heritage of Ireland, The Collins Press, Cork, Ireland, pp 499-505, 2000.

Dickerson, D. J. (2006), “Searching for Roots”, Wall Street Journal, 17 November, p. W15. Eagles, P. F. J. (1992), “The travel motivations of Canadian ecotourists”, Journal of Travel Research, (Fall), pp. 3-7. 
Eastman’s Online Genealogy Newsletter (2006, January 20), “The Family History Library - in Salt Lake City and Near You”, available at:

http://blog.eogn.com/eastmans_online_genealogy/2006/01/the_family_hist.html (accessed 17 November 2006).

Exhibiting (2008), “Who Do You Think You Are?” available at: http://www.whodoyouthinkyouarelive.co.uk (accessed 23 January 2008).

Evans, R. (1998), The Visitor's Guide to Northern Ireland, The Blackstaff Press Limited, Belfast.

“Father and Son” (2007), CitiBank television advertisement, used with permission of Publicis, New York.

Garrod, B. and Fyall, A. (2000), “Managing Heritage Tourism”, Annals of Tourism Research, Vol. 27 No. 3, pp. 682-708.

Heinlen, E. (2007), Genealogy and the economic drain on Ireland: Unintended consequences”, First Monday, Vol. 12 No. 1 (January), available at: http://firstmonday.org/issues/issue12_1/heinlen/index.html (accessed 3 June 2008).

Homecoming Scotland (2008), “Come Home and Celebrate in 2009”, available at http://www.homecomingscotland.com (accessed 17 January 2008).

Knox, D. (2008), “Spectacular Tradition: Scottish Folksong and Authenticity”, Annals of Tourism Research, Vol. 35 No. 1, pp. 255-273.

MacDonald, A. (2007), “Trump Dealt Setback on a Scottish Project”, Wall Street Journal, 30 November, p. B6. 
Mackenzie, G., Slater, G. and Roberts, H. (2004), “Family History and Tourism”, Listening to the Past, Speaking to the Future: The report of the Archives Task Force, Museums, Libraries and Archives Council, London, March.

Maclarty, L. (2008,), “Trump Furore Prompts Call for Planning Changes: Business Groups Demand Radical Overhaul”, The Aberdeen Press and Journal, Monday, 17 March, p.1.

Martin, D. (2007), “Management Learning Exercise and Trainer’s Note for Building Grounded Theory in Tourism Behavior”, Journal of Business Research, Vol. 60, pp. 742-748.

McCain, G. and Ray, N.M. (2003), “Legacy Tourism: The Search for Personal Meaning in Heritage Travel”, Tourism Management, Vol. 24, No. 6, pp. 713-717.

Nicholls, S., Vogt, C. and Jun, S.H. (2004), “Heeding the Call for Heritage Tourism”, Parks \& Recreation, (September), pp. 38-47.

Palmer, C. (2005), “An Ethnography of Englishness: Experiencing Identity through Tourism”, Annals of Tourism Research, Vol. 32 No. 1, pp. 7-27.

Ray, C. (2001), “Scottish Highland Games”, Highland Heritage, The University of North Carolina Press, Charlotte, NC.

“Scottish Roots—Dig into the Past” (2004), Scottish Executive; the Scottish Government, available at: http://www.scotland.gov.uk/News/News-Extras/56 (accessed 20 January 2008).

Silberberg, T. (1995), “Cultural Tourism and Business Opportunities for Museums and Heritage Sites”, Tourism Management, Vol. 16 No. 5, pp. 361-365.

“Tourist Board Training”, (2008), Ancestral Tourism, Events and Training, Visit Scotland, available at http://staging.scotexchange.net/ancestral_tourism-2.pdf (accessed 10 June 2008.) 
Travel Industry Association of America (2003), The Historic/Cultural Traveler. 2003 Edition.

“Trump’s Golf-Resort Plan in Play as Scottish Town Relents” (2007), Wall Street Journal, 13

December, p. A4.

Yale, P. (1991), From Tourist Attractions to Heritage Tourism, ELM Publications, Huntingdon, Cambridgeshire, UK. 


\section{Table 1}

\section{Comparisons of UK and US Citizens: Significant Differences for Motivations for Family}

History Interest: UK and US Citizens, Chi Square: $n=684$

\begin{tabular}{|c|c|c|c|c|c|c|}
\hline & US & US Not & UK & UK Not & Sig. & Percent \\
\hline Motivation & Checked & Checked & Checked & Checked & Diff. P & Checked \\
\hline Personal Identity & 241 & 298 & 69 & 76 & ns & 45.3 \\
\hline Connection with Place & 209 & 330 & 72 & 73 & $<.05$ & 41.1 \\
\hline Obligation to Ancestors & 200 & 339 & 27 & 118 & $<.05$ & 33.2 \\
\hline Intellectual Challenge & 132 & 407 & 59 & 86 & $<.05$ & 27.9 \\
\hline Discovering Continuities & 142 & 397 & 41 & 104 & ns & 26.8 \\
\hline Completing the Circle & 111 & 428 & 19 & 126 & $<.05$ & 19 \\
\hline Finding Oneself & 69 & 470 & 24 & 121 & ns & 13.6 \\
\hline Quest & 48 & 491 & 33 & 112 & $<.05$ & 11.8 \\
\hline Recovery of Social Identity & 54 & 485 & 15 & 130 & ns & 10.1 \\
\hline Sacred & 65 & 474 & 2 & 143 & $<.05$ & 9.8 \\
\hline Closing the Gap & 42 & 497 & 21 & 124 & $<.05$ & 9.2 \\
\hline Community & 58 & 481 & 2 & 143 & $<.05$ & 8.8 \\
\hline True Home & 48 & 491 & 8 & 137 & ns & 8.2 \\
\hline Magical Feeling & 44 & 494 & 12 & 133 & ns & 8.2 \\
\hline Inward Journey & 40 & 499 & 5 & 140 & ns & 6.6 \\
\hline Homecoming & 43 & 496 & 1 & 144 & $<.05$ & 6.4 \\
\hline Pilgrimage & 31 & 508 & 4 & 141 & ns & 5.1 \\
\hline
\end{tabular}

Bold indicates the sample with the larger proportion checked.

Note: Future versions will include Medical/DNA as a motivator due to responses to "Other” on research instruments. 
Table 2

\section{Demographic Comparison of Means between UK and US Samples}

$$
\text { US: } n=539, \text { UK: } n=145 \text {, may be less for nonresponse }
$$

\begin{tabular}{|c|c|c|c|}
\hline & Country of Citizenship & Mean* & $\begin{array}{c}\text { Significance } \\
\text { t-value }\end{array}$ \\
\hline \multicolumn{4}{|l|}{$\begin{array}{l}\text { Age and Background } \\
\text { of Respondents }\end{array}$} \\
\hline \multirow[t]{2}{*}{ age } & United States of America & 56.70 & \multirow{2}{*}{$\begin{array}{l}<.01 \\
-9.90\end{array}$} \\
\hline & United Kingdom & 65.94 & \\
\hline \multirow[t]{2}{*}{ Percent Foreign travel } & United States of America & 13.66 & \multirow{2}{*}{$\begin{array}{c}<.01 \\
-4.44\end{array}$} \\
\hline & United Kingdom & 25.57 & \\
\hline \multirow[t]{2}{*}{$\begin{array}{l}\text { Percent Non-business } \\
\text { travel }\end{array}$} & United States of America & 77.85 & \multirow{2}{*}{$\begin{array}{c}.02 \\
-2.35\end{array}$} \\
\hline & United Kingdom & 84.96 & \\
\hline \multicolumn{4}{|l|}{$\begin{array}{l}\text { Importance of } \\
\text { Reasons for Typical } \\
\text { Leisure Travel }\end{array}$} \\
\hline $\begin{array}{l}\text { People of similar } \\
\text { interests }\end{array}$ & United States of America & 2.31 & \multirow{2}{*}{$\begin{array}{c}.18 \\
-1.35\end{array}$} \\
\hline & United Kingdom & 2.43 & \\
\hline \multirow[t]{2}{*}{ Together as a family } & United States of America & 1.49 & \multirow{2}{*}{$\begin{array}{c}<.01 \\
-4.88\end{array}$} \\
\hline & United Kingdom & 1.97 & \\
\hline \multirow[t]{2}{*}{ Where I feel safe } & United States of America & 2.12 & \multirow{2}{*}{$\begin{array}{l}<.01 \\
-4.49\end{array}$} \\
\hline & United Kingdom & 2.63 & \\
\hline \multirow[t]{2}{*}{$\begin{array}{l}\text { Where my family is } \\
\text { from }\end{array}$} & United States of America & 1.80 & \multirow{2}{*}{$\begin{array}{l}.34 \\
-.95\end{array}$} \\
\hline & United Kingdom & 1.90 & \\
\hline \multirow[t]{2}{*}{$\begin{array}{l}\text { Visiting friends and } \\
\text { relatives }\end{array}$} & United States of America & 1.56 & \multirow{2}{*}{$\begin{array}{c}.03 \\
-2.20\end{array}$} \\
\hline & United Kingdom & 1.74 & \\
\hline \multirow[t]{2}{*}{$\begin{array}{l}\text { creating } \\
\text { friends/relationships }\end{array}$} & United States of America & 2.09 & \multirow{2}{*}{$\begin{array}{l}<.01 \\
-5.38\end{array}$} \\
\hline & United Kingdom & 2.68 & \\
\hline
\end{tabular}

*other than for age and percent of travel (first three items in table), lower numbers represent higher levels of importance when traveling (Likert-type scale of $1=$ very important to $5=$ not at all important) 
Figure 1

\section{Actual summary itineraries of recent legacy group bus trips}

(Welsh-Americans to Scotland and Wales, and a North American Clan to Scotland).

\begin{tabular}{|c|c|c|}
\hline & $\begin{array}{l}\text { Mormon Welsh-Americans to } \\
\text { Scotland and Wales }(n=29)\end{array}$ & $\begin{array}{l}\text { One North American Clan Trip to } \\
\text { Scotland }^{1}(n=30)\end{array}$ \\
\hline $\begin{array}{l}\text { Demographics of Group: } \\
\text { - } \text { Average age } \\
\text { - } \text { Age range } \\
\text { - } \text { Men/Women } \\
\text { - } \\
\quad \text { inerage \# ancestral trips } \\
\text { in past two years } \\
\end{array}$ & $\begin{array}{ll}\text { - } & 66 \\
\text { - } & 45-79 \\
\text { - } & 33 \% / 67 \% \\
\text { - } & 1.3\end{array}$ & $\begin{array}{ll}- & 61 \\
\text { - } & 34-79 \\
\text { - } & 37 \% / 63 \% \\
\text { - } & 1.4\end{array}$ \\
\hline Day 1 & $\begin{array}{l}\text { Stiling Castle; Glasgow. } \\
\text { Ancestral homes of some tour } \\
\text { participants. } \\
\text { Shopping. }\end{array}$ & $\begin{array}{l}\text { Tour of Glasgow. } \\
\text { Kelvingrove Museum. }\end{array}$ \\
\hline 2 & $\begin{array}{l}\text { Edinburgh Castle. } \\
\text { Round of golf. }\end{array}$ & $\begin{array}{l}\text { Stirling Castle and Wallace } \\
\text { Monument. } \\
\text { Sheriffmuir Battlefield (relevant to } \\
\text { particular clan). } \\
\text { Bannockburn Battlefield. }\end{array}$ \\
\hline 3 & $\begin{array}{l}\text { Tour of Glasgow. } \\
\text { Ancestral homes of some tour } \\
\text { participants. } \\
\text { Ayrshire-Alloway, birthplace } \\
\text { of Robert Burns. }\end{array}$ & $\begin{array}{l}\text { Area of Scotland particularly } \\
\text { relevant to clan. Local churchyard } \\
\text { ruins of clan. } \\
\text { Eilean Donan Castle (said to be } \\
\text { the most photographed castle in } \\
\text { Scotland), relevant to clan. }\end{array}$ \\
\hline 4 & $\begin{array}{l}\text { Carlisle and Hadrian’s Wall. } \\
\text { Preston, home of church } \\
\text { missionary work. }\end{array}$ & $\begin{array}{l}\text { Plockton. The BBC series, } \\
\text { "Hamish MacBeth" was filmed } \\
\text { here. } \\
\text { Couple renewing wedding vows at } \\
\text { Eilean Donan Castle. }\end{array}$ \\
\hline 5 & $\begin{array}{l}\text { Liverpool Merseyside } \\
\text { Maritime Museum. } \\
\text { North Wales. }\end{array}$ & $\begin{array}{l}\text { Trip to Western Isles, including } \\
\text { Callanish standing stones on the } \\
\text { Isle of Lewis. Western Isles } \\
\text { visited not particularly relevant to } \\
\text { clan. }\end{array}$ \\
\hline 6 & Caernarvon Castle, where & Western Isles, Isle of Harris. \\
\hline
\end{tabular}

\footnotetext{
${ }^{1}$ For the 2009 Homecoming clan gathering, the trip will go to Inverness and the Orkney Islands instead of the Western Isles.
} 


\begin{tabular}{|l|l|l|}
\hline & $\begin{array}{l}\text { investiture of Prince Charles } \\
\text { took place. } \\
\text { Shopping. } \\
\text { Round of golf. }\end{array}$ & Shopping for Harris Tweed. \\
\hline 7 & $\begin{array}{l}\text { Slate caverns. } \\
\text { Narrow-gauge railway. } \\
\text { Aberystwyth. }\end{array}$ & $\begin{array}{l}\text { Western Isles, Flora MacDonald's } \\
\text { birthplace. }\end{array}$ \\
\hline 8 & $\begin{array}{l}\text { National Library of Wales } \\
\text { (Aberystwyth). } \\
\text { Ancestral homes. } \\
\text { Bowling green. }\end{array}$ & $\begin{array}{l}\text { Oban. } \\
\text { Iveraray Castle. }\end{array}$ \\
\hline 9 & $\begin{array}{l}\text { Cenarth Falls to see ancient } \\
\text { Welsh fishing boats (coracles). } \\
\text { Laughrne (Dylan Thomas boat } \\
\text { house). }\end{array}$ & $\begin{array}{l}\text { Kintyre Peninsula. } \\
\text { Isle of Arran. }\end{array}$ \\
\hline 10 & $\begin{array}{l}\text { Llanelli, where many ancestors } \\
\text { were baptized. } \\
\text { Cardiff Castle. }\end{array}$ & \begin{tabular}{l} 
Isle of Arran. \\
\hline 11
\end{tabular} \\
$\begin{array}{l}\text { Sunday: day of Church } \\
\text { meetings and visits to areas } \\
\text { where ancestors were baptized. }\end{array}$ & $\begin{array}{l}\text { Edinburgh Festival and the } \\
\text { Military Tattoo }\end{array}$ \\
\hline 12 & Big Pit Mining Museum. & $\begin{array}{l}\text { Ayreshire, and birthplace of } \\
\text { Robert Burns (Alloway) }\end{array}$ \\
\hline
\end{tabular}

